\title{
THE
}

\section{Influence of Summer Biogeography on Wood Warbler Stopover}

\section{Abundance}

Jeffrey F. Kelly

Rob Smith

Deborah M. Finch

Frank R. Moore

Wang Yong

University of Rhode Island

Follow this and additional works at: https://digitalcommons.uri.edu/nrs_facpubs

\section{Citation/Publisher Attribution}

Kelly, J., Smith, R., Finch, D., Moore, F., \& Yong, W. (1999). Influence of Summer Biogeography on Wood Warbler Stopover Abundance. The Condor, 101(1), 76-85. doi:10.2307/1370448

Available at: http://dx.doi.org/10.2307/1370448

This Article is brought to you for free and open access by the Natural Resources Science at DigitalCommons@URI. It has been accepted for inclusion in Natural Resources Science Faculty Publications by an authorized administrator of DigitalCommons@URI. For more information, please contact digitalcommons-group@uri.edu. 
Influence of Summer Biogeography on Wood Warbler Stopover Abundance

Author(s): Jeffrey F. Kelly, Rob Smith, Deborah M. Finch, Frank R. Moore and Wang Yong

Source: The Condor, Vol. 101, No. 1 (Feb., 1999), pp. 76-85

Published by: American Ornithological Society

Stable URL: https://www.jstor.org/stable/1370448

Accessed: 12-09-2018 16:26 UTC

\section{REFERENCES}

Linked references are available on JSTOR for this article: https://www.jstor.org/stable/1370448?seq=1\&cid=pdf-reference\#references_tab_contents You may need to log in to JSTOR to access the linked references.

JSTOR is a not-for-profit service that helps scholars, researchers, and students discover, use, and build upon a wide range of content in a trusted digital archive. We use information technology and tools to increase productivity and facilitate new forms of scholarship. For more information about JSTOR, please contact support@jstor.org.

Your use of the JSTOR archive indicates your acceptance of the Terms \& Conditions of Use, available at https://about.jstor.org/terms

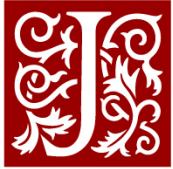

American Ornithological Society is collaborating with JSTOR to digitize, preserve and extend access to The Condor 


\title{
INFLUENCE OF SUMMER BIOGEOGRAPHY ON WOOD WARBLER STOPOVER ABUNDANCE ${ }^{1}$
}

\author{
JEFFREY F. KELLY \\ USDA Forest Service, Rocky Mountain Research Station, 2205 Columbia SE, Albuquerque, NM 87106, \\ e-mail: jkelly/rmrs_albq@fs.fed.us \\ RoB SMITH \\ Department of Biological Sciences, University of Southern Mississippi, Box 5018, \\ Hattiesburg, MS 39406-5018 \\ Deborah M. FINCH \\ USDA Forest Service, Rocky Mountain Research Station, 2205 Columbia SE, Albuquerque, NM 87106
}

Frank R. MOORE

Department of Biological Sciences, University of Southern Mississippi, Box 5018, Hattiesburg, MS 39406-5018

WANG YONG

Department of Natural Resources Science, University of Rhode Island, Kingston, RI 02881

\begin{abstract}
We evaluated the effect of summer biogeography of migrant wood warblers (Parulidae) on their stopover abundance. To characterize abundance patterns, we used mistnet capture data from spring and fall migration in the Middle Rio Grande Valley, New Mexico, spring migration on the Gulf Coast of Louisiana, and fall migration on the Gulf Coast of Alabama. To describe the summer biogeography of 47 species of wood warblers, we used indices of their summer range size, their summer density, and distance between their summer ranges and our netting sites. Multiple linear regressions indicated that biogeographic indices explained $55 \%$ and $49 \%$ of variation in captures in the Middle Rio Grande Valley during spring and fall, respectively. On the Gulf Coast these regressions explained $25 \%$ of the variation during spring at the Louisiana site and $51 \%$ during fall at the Alabama site. Both summer range size and distance between the summer range and study sites explained significant portions of the variation in three of the four analyses. Interestingly, the importance of biogeographic factors was least evident among spring migrants along the Gulf Coast of Louisiana. The difference between this site and other sites may reflect differences between migrants arriving after a Gulf crossing and those migrating across continental land masses or possibly an increased importance of winter biogeography for migrants crossing the Gulf of Mexico in the spring. In general, these results indicate that abundance of migrant warblers at our netting sites in both the eastern and western United States during spring and fall migration were influenced by summer biogeography. Consequently, we suggest including biogeographic analyses in assessments of conservation priorities for local stopover sites.
\end{abstract}

Key words: $\quad$ biogeography, Gulf Coast, Middle Rio Grande Valley, migration, Parulidae, stopover, wood warbler.

\section{INTRODUCTION}

Recent analyses of Breeding Bird Survey data have generated concern about declining population trends of Neotropical migrant land birds (Robbins et al. 1989, Peterjohn et al. 1995, James et al. 1996). Coincident with recent attention to trends in numbers of breeding birds has been an increased awareness that these trends

\footnotetext{
'Received 29 June 1998. Accepted 20 October 1998.
}

reflect not only the condition of breeding habitat, but also that of migration and winter habitats. This awareness has led to a new focus on ecology of en route migrants (Moore et al. 1990, Moore and Simons 1992, Moore et al. 1995). Recent research on en route migrants differs from most previous work on migration in its aim to improve the population status of these species. A primary objective has been to understand the factors that determine the abundance of en route migrants at local stopover sites. In contrast to extensive biogeographic analyses done to un- 
derstand patterns of local abundance among breeding birds, few analyses of this sort have been used to examine patterns of local abundance at stopover sites.

Biogeography is an established determinant of breeding bird abundance at local sites (Gaston 1994, Brown and Lomolino 1998). For instance, species with large breeding ranges tend to be more common breeders at local sites (Gaston and Curnutt 1998), and species tend to be more abundant at the center than at the edge of their breeding range (Brown et al. 1995). Furthermore, biogeographic analyses have implications for the conservation of breeding birds (Lawton 1993, Maurer and Heywood 1993, Mehlman 1994).

Conceptual and empirical studies also indicate the importance of biogeography for en route migrants (Hutto 1985, Moore et al. 1995). Examples of biogeographic patterns among en route migrants include: (1) concentrations of birds on peninsulas and near-shore islands that have been linked to the probability of migrants successfully crossing migration barriers, such as the Gulf of Mexico and Sahara Desert (Biebach et al. 1986, Moore and Kerlinger 1987), (2) songbird concentrations along coastal regions relative to the interior of continents (Moore et al. 1995), and (3) concentrations of migrants in riparian zones in arid regions like the interior western United States (Finch and Yong, in press). These wellknown patterns indicate the potential for biogeographic factors to influence the abundance of migrant songbirds at stopover sites.

In addition to these patterns, there are numerous other questions that could be addressed with biogeographic data. For instance, are stopover sites that are situated between the breeding and wintering range of many species used by more species than sites not in this position? If so, this effect may help explain regional differences in abundance of some migratory birds at stopover sites in the eastern United States relative to the western U.S. (Moore et al. 1995). Proximity of stopover sites to breeding or winter range also may influence use of those sites. For example, do species that breed or winter near a stopover site occur with greater abundance at that site than species that breed or winter farther away? Range size also might influence stopover abundance. That is, do species with large breeding or winter ranges generally occur in greater abundance at stopover sites? Finally, breeding or winter density might be related to stopover abundance. Thus, species with high breeding or winter densities might have higher stopover abundances than species with sparse breeding and wintering populations.

The data available on summer distribution and density far surpass those available for winter, although the amount of information available on winter distributions of Neotropical migrants has increased recently (Ridgely and Tudor 1989, Howell and Webb 1995). We felt that reliable estimates of the biogeographic parameters we were interested in could only be derived from summer ranges. Therefore, we focus solely on summer biogeography and its ability to explain wood warbler capture data from stopover sites in New Mexico, Alabama, and Louisiana during spring and fall.

Wood warblers have been the focus of conservation concern. Rappole et al. (1983) indicated that 19 species of wood warblers that commonly occur in the U.S. were at risk. In developing a scheme for ranking conservation priorities, Reed (1993) focused on wood warblers and vireos (Vireonidae). Finally, of the 44 species of wood warblers whose population trends were examined by Price et al. (1995), 11 displayed significant declines in relative abundance on the breeding grounds between 1984 and 1993 . We focused on migrating wood warblers because of these important conservation issues and because: (1) the relatively large number of wood warbler species provides an adequate sample size for meaningful analyses while limiting taxonomic variation that can confound such analyses and (2) a fairly large number of wood warbler species were captured at each stopover site.

\section{METHODS}

\section{STUDY SITES}

The Middle Rio Grande Valley is a $260-\mathrm{km}$ long reach of river between Cochiti Dam and Elephant Butte Reservoir in New Mexico. Within the Middle Rio Grande Valley our two study sites were the Rio Grande Nature Center $\left(35^{\circ} 07^{\prime} \mathrm{N}, \mathrm{W} 106^{\circ} 41^{\prime} \mathrm{N}\right.$; hereafter Nature Center) and the Bosque del Apache National Wildlife Refuge $\left(33^{\circ} 48^{\prime} \mathrm{N}, 106^{\circ} 52^{\prime} \mathrm{W}\right.$; hereafter Bosque del Apache). The mist-net areas in the Middle Rio Grande Valley were chosen because they contained a diversity of habitat types in close proximity $(<1 \mathrm{~km}$ apart). The primary riparian 
vegetation in these areas are bosques dominated by cottonwood (Populus fremontii), Russian olive (Elaeagnus angustifolia), saltcedar (Tamarix ramosissima), and willow (Salix gooddingii and S. exigua). Large numbers of migrants use these habitats as migration stopover sites (Yong and Finch 1997, Yong et al. 1998, Finch and Yong, in press).

The two Gulf Coast study sites were Ft. Morgan, Alabama, and Johnson's Bayou, Louisiana. The Ft. Morgan site was located within Bon Secour National Wildlife Refuge $\left(30^{\circ} 10^{\prime} \mathrm{N}\right.$, $88^{\circ} 00^{\prime} \mathrm{W}$ ) on Ft. Morgan peninsula about $15 \mathrm{~km}$ west of Gulf Shores, Alabama. This site was characterized by scattered slash pine (Pinus elliotti) interspersed among hummocks of sand live oak (Quercus geminata) and yaupon (Ilex vomitoria). The Johnson's Bayou site was located in Cameron Parish, Louisiana $\left(29^{\circ} 45^{\prime} \mathrm{N}\right.$, $93^{\circ} 37^{\prime} \mathrm{W}$ ) about $30 \mathrm{~km}$ east of Port Arthur, Texas. This site was dominated by live oak $(Q$. virginiana) and hackberry (Celtis laevigata) canopy with an understory of yaupon, deciduous holly (Ilex decidua), sweet acacia (Acacia farnesiana), and a number of vines (e.g., Smilax tamnoides, Vitis cinerea, Toxicodendron radicans).

\section{MIST-NET DATA}

From 1994 to 1996 , we used 20 mist nets $(12 \times$ $2.6 \mathrm{~m}, 30$ or $36 \mathrm{~mm}$ mesh) to capture spring (mid April to early June) and fall migrants (early August to early November) at the Bosque del Apache and the Nature Center. At Johnson's Bayou, 20 nets were operated in the spring of 1994 through 1996, and at Ft. Morgan 23, 24, and 29 nets were operated in the fall of 1994, 1995, and 1996, respectively. In the Middle Rio Grande Valley, nets were opened 15 min prior to sunrise and remained opened for about $6 \mathrm{hr}$ $\mathrm{day}^{-1}$ except during inclement weather. On the Gulf Coast, nets were opened shortly after sunrise, sometimes closed at midday due to high temperatures, and then reopened in the evening. At the Bosque del Apache, nets were operated for between 4,500 and 7,700 net-hr in each spring and fall for a total of 47,102 net-hr. At the Nature Center, nets were operated between 4,800 and 11,700 net-hr in each season of each year for a total of 49,003 net-hr. At Johnson's Bayou, nets were operated between 7,400 and 8,000 net-hr each spring for a total of 22,937 net-hr. At Ft. Morgan, nets were operated be- tween 6,900 and 9,800 net-hr each fall for a total of 24,242 net-hr. Nets were checked at 20-30 min intervals. All birds were marked with a uniquely numbered aluminum leg band.

Like most methods of sampling wild vertebrate populations, mist netting has a number of shortcomings. For instance, changes in vegetation over time can cause serious problems in interpretation of netting data. Recently there have been several reviews of the use of bird captures at standardized mist-net stations to index population trend or density; their results have differed widely. Hussell and Ralph (1995) advocated the use of mist-net stations for this purpose with careful attention to methodology. Dunn et al. (1997) found evidence that, with attention to potential biases, standardized netting could be used to monitor populations. Remsen and Good (1996), however, argued that no currently used mist-netting scheme could reliably estimate relative abundance. Most of the deficiencies pointed out by Remsen and Good have been identified previously (MacArthur and MacArthur 1974, Karr 1981) and these deficiencies are a subset of those that apply to most capture and census methods (Bibby et al. 1992). Therefore, while use of mist-net captures as a measure of relative abundance has serious limitations, there is no indication that these limitations are greater than those of other census techniques. For these reasons, we cautiously treat captures at mist nets as an index of the abundance of birds in the net area.

\section{BIOGEOGRAPHY DATA}

We used three variables to describe the summer distribution of wood warblers. Because previous analyses of biogeography have indicated that both range size and density of birds significantly influence their occurrence at local sites (Gaston 1994), we used indices of these variables. We used range size as an index of how widespread a species was, in contrast with density which we used as an index of a species' maximum local abundance. The third variable we used was the minimum distance from our study area to the edge of the breeding range of each species. We measured this variable because we predicted that stopover sites close to where a species' breeds would be more likely to be used than distant sites. We predicted that range size and density would be positively correlated with number of captures, and that distance between each study 
site and the summer range of warblers would be negatively correlated with number of captures. Thus, species that have large ranges, dense populations, and that breed close to our banding stations should be caught often, whereas species that have small ranges, sparse populations, and breed far from our banding stations should be caught infrequently.

To obtain the data we needed, we used range maps and tables presented by Price et al. (1995) for 47 species of wood warblers caught at our sites (Table 1). Although all 47 species were not captured at any one site, they were all included in each analysis. We include all wood warbler species because we wanted to predict the number of captures for each species. Species that were not captured provided as much information as those that were captured. In fact, eliminating species we did not catch could artificially inflate our predictive power. For instance, if we predicted that we would catch thousands of individuals of some species but in reality caught none, then eliminating these data would mask deficiencies in our predictions. The only wood warbler species that breed in the U.S. but were not included in the analyses were Bachman's Warbler (Vermivora bachmanii), Colima Warbler (V. crissalis), Golden-cheeked Warbler (Dendroica chrysoparia), Kirtland's Warbler (D. kirtlandii), and Tropical Parula (Parula pitiayumi). We excluded these species because Price et al. (1995) did not provide range maps for them.

We indexed range size by overlaying a dot grid on the maps presented by Price et al. (1995). We used the number of dots in areas of known size to convert the number of dots counted in each range into area $\left(\mathrm{km}^{2}\right)$. We also used these maps to estimate the minimum distance between the breeding range of each species and the study sites. Because the study sites in the Middle Rio Grande Valley were close together on a biogeographic scale, about $100 \mathrm{~km}$ apart, we pooled data from these sites for analysis. This pooling was justified because separate analyses of data from the two Middle Rio Grande sites showed no substantial differences from the pooled analysis. Finally, we used the highest frequency of detections reported in Price et al.'s (1995) annotated list of species detected on Breeding Bird Survey Routes as an index of the summer density of warbler populations. These data are the number of birds of a given species detected on a given Breeding Bird Survey route averaged over four to seven years. The data used were from "routes that have regularly detected high numbers of individuals of that species" (Price et al. 1995).

A persistent problem in understanding biogeographic effects is that accurate maps of species' distributions are difficult to produce. Recent efforts, notably the Breeding Bird Survey, have improved the accuracy and reliability of distribution maps for birds that occur in the U.S. during the summer. Despite this improvement, lack of basic distribution information continues to hamper large-scale analyses. The advantage of the maps presented by Price et al. (1995) is that they are the product of standardized data collection and rigorous analysis. The drawback of using these maps is that, because they are based on Breeding Bird Survey routes, they are truncated at northern latitudes and are a poor representation of species that occur away from roads. Truncation at northern latitudes probably led us to underestimate the range size of warblers that occur primarily at high latitudes. We estimate that our measurements of the index of range size were truncated by the available map in 23 of the 47 species whose ranges we measured. Of these, comparisons with maps in field guides (Scott 1987) indicated that our measurements underestimated the range size of 10 species whose distributions extend into northwestern Canada and Alaska. Most of these 10 species, however, are widely distributed, and thus our index still indicated that they had large ranges. Despite these limitations, we felt that Price et al. (1995) was the most rigorous and standardized source for information on the summer ranges of wood warblers, and we think that the index we used did reflect real variation in the size of warblers' ranges.

\section{STATISTICAL ANALYSIS}

We used the total number of individuals captured of each species at each site in each season as the response variable (Table 1) in multiple linear regression analyses. These analyses were designed to determine how much of the variation in number of captures was due to the biogeographic indices. All 47 species were included in each analysis even though all species were not captured at any one site in any season. Because the frequency distribution of captures was lognormally distributed, we added 1 to the number of captures of all species and then log trans- 


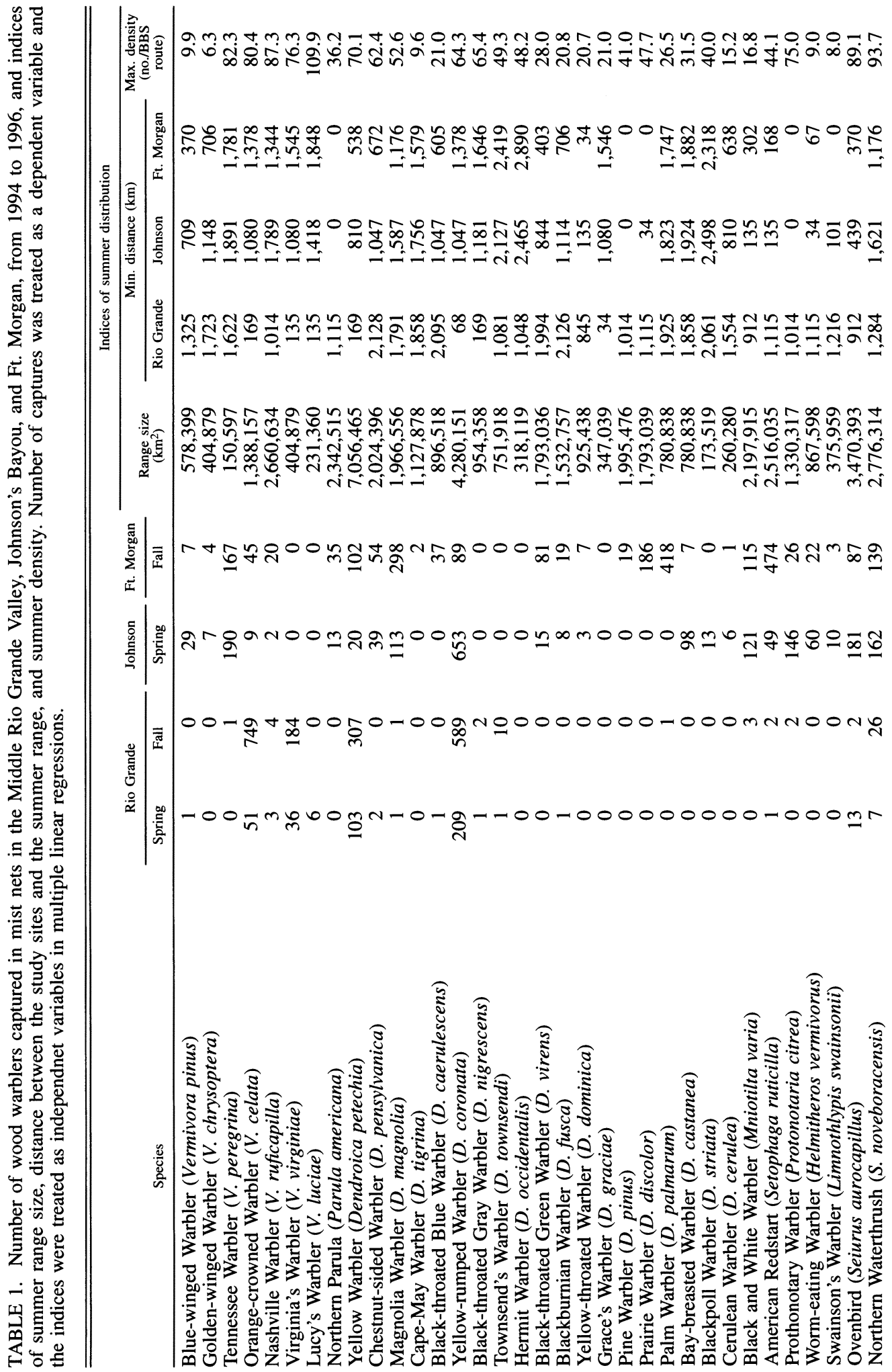




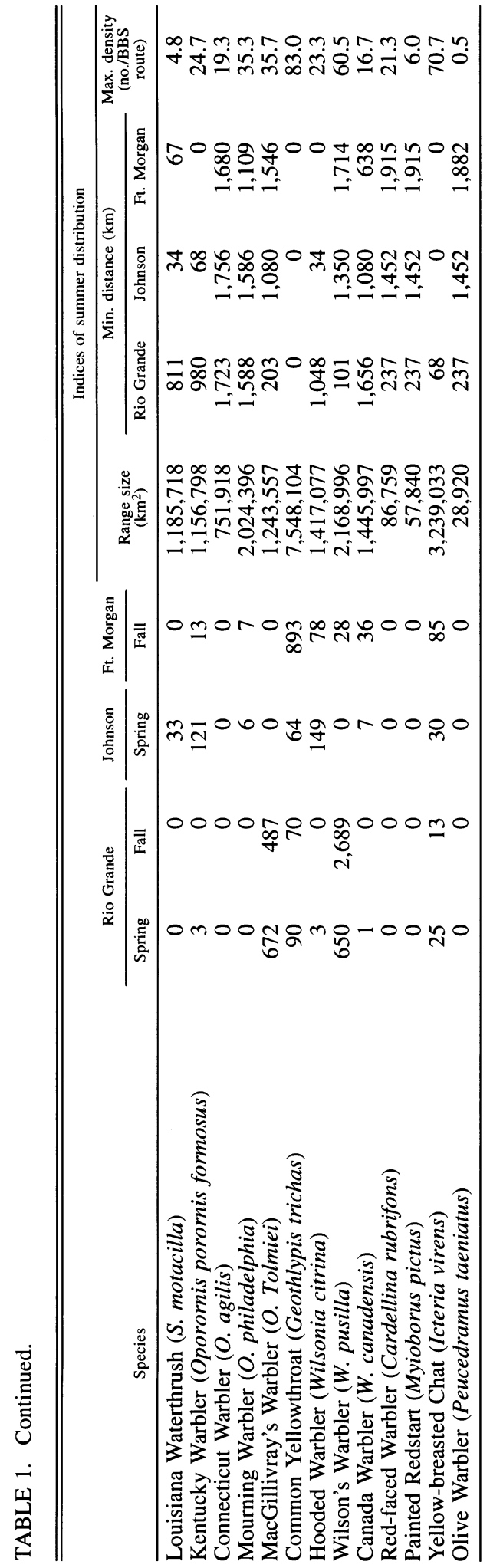

formed the data (Sokal and Rohlf 1981). Indices of range size, density, and distance from the breeding ground were used as the independent variables. Because the data in these regressions do not represent a sample from a larger population of wood warbler species and their residuals were not normally distributed, we used a bootstrap procedure (SPSS 1997) to estimate the regression coefficients and their $95 \%$ confidence intervals. The bootstrap approach has the added advantage of avoiding homogeneity of variance and normality assumptions associated with parametric multiple linear regression. We considered regression coefficients to be significant if their 95\% confidence intervals did not overlap zero. Because our indices of summer range size and distance between the summer range and study sites were collinear, we used partial correlations to better understand the relationship between each index and capture rates. In all analyses we lumped captures from all three years of sampling for three reasons: (1) multiple linear regression analyses that related the number of captures in each year to biogeographic indices did not improve our ability to explain variation in stopover abundance, (2) these relationships were similar among years for a given site and season, and (3) we think that pooling these data across years improves our estimate of the relative abundance of each species and thereby the robustness of the analysis.

\section{RESULTS}

\section{CAPTURE DATA}

Of the 28 species of wood warblers captured in the Middle Rio Grande Valley, 21 were captured at the Nature Center, 25 at the Bosque del Apache, and 18 at both sites. At both Middle Rio Grande Valley sites combined, there were 23 warbler species captured in the spring and 19 in the fall (Table 1). One hybrid (Lawrence's Warbler, Vermivora pinus $\times V$. chrysoptera) was captured at the Nature Center; this individual was excluded from analyses. About half the species captured in each season in the Middle Rio Grande Valley had abundances of 10 or fewer individuals (14 of 23 species in the spring and 9 of 19 in the fall). The seven most common species in both seasons in the Middle Rio Grande were Common Yellowthroats (Geothlypis trichas), MacGillivray's Warblers (Oporornis tolmiei), Orange-crowned Warblers (Vermivora 

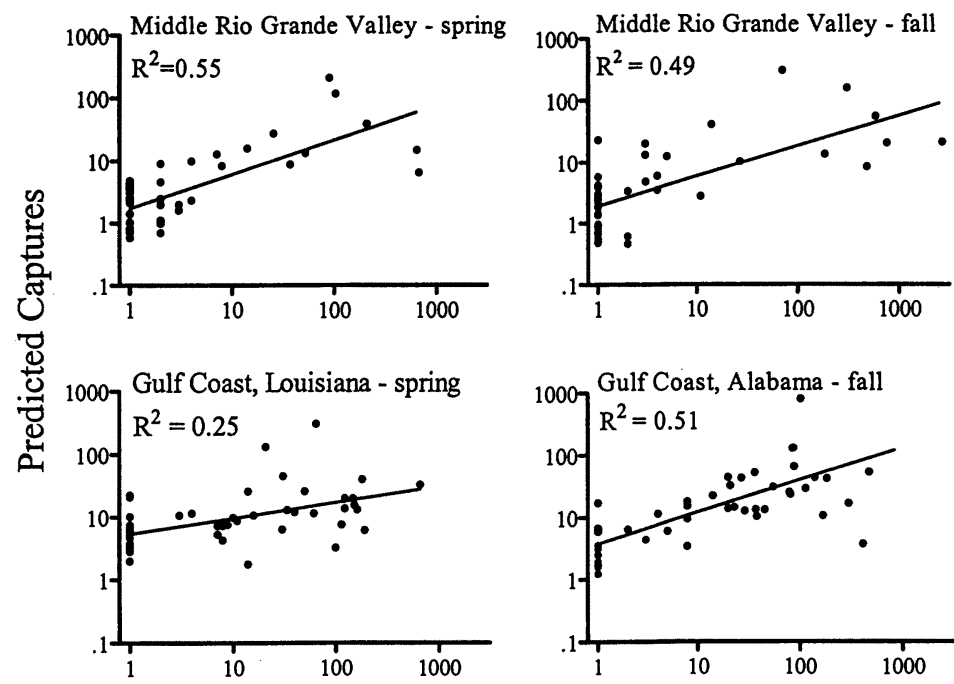

\section{Observed Captures (+1)}

FIGURE 1. Log of the predicted number of captures plotted against log of the actual number of captures of 47 species of wood warblers. Note that all 47 species were not captured in any season at any one site. Predicted captures were derived from multiple regression analysis of indices of breeding range size $\left(\mathrm{km}^{2}\right)$, minimum distance between the study sites and breeding range $(\mathrm{km})$, and maximum breeding density (no./BBS route). Least-square regression lines are shown for each plot.

celata), Virginia's Warblers (V. virginiae), Wilson's Warblers (Wilsonia pusilla), Yellow-rumped Warblers (Dendroica coronata), and Yellow Warblers (D. petechia). The rank abundances of these species differed between seasons.

Of the 36 species captured on the Gulf Coast between 1994 and 1996, 34 were caught in the fall at Ft. Morgan, 30 in the spring at Johnson's Bayou, and 28 at both sites. In contrast to the Middle Rio Grande sites, less than one third of species caught along the Gulf Coast were represented by captures of 10 or fewer individuals ( 8 species at Ft. Morgan and 9 at Johnson's Bayou). Warbler abundance appeared to be more variable between seasons (or sites) on the Gulf Coast than in the Middle Rio Grande Valley. For instance, none of the five most commonly captured species at either site was among the top five captured at the other site. Because we sampled Gulf Coast sites in only one season, however, it is impossible to determine whether variation in captures was primarily a site or season effect. Common Yellowthroats were by far the most common species captured at Ft. Morgan, whereas Yellow-rumped Warblers were the most frequently captured species at Johnson's Bayou.

\section{BIOGEOGRAPHIC PATTERNS}

In the Middle Rio Grande Valley, multiple linear regression analysis revealed that the indices of range size, distance to summer range, and density explained $55 \%$ and $49 \%$ of the variation in capture data during spring and fall, respectively (Fig. 1). Regression and partial correlations coefficients indicated that range size and density were positively associated with number of captures, whereas distance between the study site and the breeding range was negatively associated with number of captures (Table 2 and 3). Coefficients for range size and distance between the breeding range and study sites were significantly different from zero, but those for density were not (Table 2 and 3).

On the Gulf Coast, the biogeographic indices explained $25 \%$ of the variation in captures of wood warblers at Johnson's Bayou in the spring and $51 \%$ of the variation in captures at Ft. Morgan in the fall (Fig. 1). The relationship between wood warbler captures and the biogeographic indices at Ft. Morgan was similar to patterns in the Middle Rio Grande. That is, indices of summer range size and distance between the study area and the summer range explained a signifi- 
TABLE 2. Coefficients of biogeographic indices used as independent variables in multiple linear least-square regressions. The $\log$ number of captures $(+1)$ of 47 species of wood warblers was used as the dependent variable. The indices were summer range size, minimum distance between the study area and the summer range, and the maximum summer density for each species of wood warbler.

\begin{tabular}{lllll}
\hline \hline \multirow{2}{*}{ Site } & & \multicolumn{2}{c}{ Regression coefficients for independent variables $^{\mathrm{a}}$} \\
\cline { 3 - 5 } & Season & Range size $\left(\mathrm{km}^{2}\right)$ & Min. distance $(\mathrm{km})$ & $\begin{array}{c}\text { Max. density } \\
\text { (no./BBS route) }\end{array}$ \\
\hline Middle Rio Grande Valley & spring & $1.78 \times 10^{-7 *}$ & $-4.72 \times 10^{-4 *}$ & $6.07 \times 10^{-3}$ \\
& fall & $1.71 \times 10^{-7 *}$ & $-5.75 \times 10^{-4 *}$ & $7.63 \times 10^{-3}$ \\
& & & & \\
Gulf Coast & spring & $1.87 \times 10^{-7}$ & $-3.07 \times 10^{-4}$ & $2.17 \times 10^{-3}$ \\
Johnson's Bayou & fall & $1.38 \times 10^{-7 *}$ & $-3.55 \times 10^{-4 *}$ & $7.93 \times 10^{-3}$ \\
Ft. Morgan & &
\end{tabular}

a* Coefficients for which bootstrap estimates of $95 \%$ confidence intervals do not overlap zero.

cant portion of the variation in captures, whereas the index of maximum density was not significant (Table 2). At Johnson's Bayou, however, none of the regression or partial correlation coefficients were significant (Table 2 and 3).

\section{DISCUSSION}

Our indices of summer biogeography explained a surprisingly high percentage of the variation in captures of en route migrant wood warblers in the Middle Rio Grande Valley and at Ft. Morgan on the Gulf Coast. Although trends at Johnson's Bayou were similar, they were not significant. Even though the degree to which the patterns we report are influenced by sampling bias is unknown, several factors suggest that sampling bias was not their primary cause. First, there is no reason to expect a relationship between biogeographic indices and sampling bias at local net-stations. Second, even though the species and number of individuals captured in the Middle Rio Grande Valley differed markedly from those caught on the Gulf Coast, the biogeographic patterns remained largely consistent. Therefore, we argue that summer biogeography of wood warblers was an important factor in explaining their stopover abundance during both spring and fall migration at our sites which were located in the eastern and western U.S.

Of the indices we used, summer range size and distance between the summer range and study sites were consistently important in explaining capture data. This positive relationship between range size and a species' abundance at local sites is similar to those shown in other taxa (Bock 1987, Gotelli and Simberloff 1987, Gaston 1988). These previous studies have been concerned with local abundance at sites used by breeding individuals or permanent residents. Our data suggest that this relationship also is evident for en route migrants. In contrast to these patterns, our density index did not explain a significant portion of the variation in wood warbler captures at any of our sites. It seems likely that a true measure of summer density would provide

TABLE 3. Partial correlation coefficients for the relationship between log number of captures of 47 species of migrant wood warblers and three indices of their summer biogeography. The indices used were summer range size, minimum distance between the summer range and the study areas, and maximum summer density. Coefficients reflect the relationship between log capture rates and one of the indices when the effects of the other two indices are controlled.

\begin{tabular}{|c|c|c|c|c|c|c|c|}
\hline \multirow[b]{2}{*}{ Site } & \multirow[b]{2}{*}{ Season } & \multicolumn{2}{|c|}{ Range size $\left(\mathrm{km}^{2}\right)$} & \multicolumn{2}{|c|}{ Min. distance $(\mathbf{k m})$} & \multicolumn{2}{|c|}{ Max. density (no./BBS route) } \\
\hline & & $r$ & $P$ & $r$ & $P$ & $r$ & $P$ \\
\hline \multicolumn{8}{|c|}{ Middle Rio Grande Valley } \\
\hline Sites combined & $\begin{array}{l}\text { spring } \\
\text { fall }\end{array}$ & $\begin{array}{l}0.41 \\
0.32\end{array}$ & $\begin{array}{l}0.01 \\
0.01\end{array}$ & $\begin{array}{l}-0.50 \\
-0.48\end{array}$ & $\begin{array}{l}<0.01 \\
<0.01\end{array}$ & $\begin{array}{l}0.27 \\
0.27\end{array}$ & $\begin{array}{l}0.08 \\
0.08\end{array}$ \\
\hline \multicolumn{8}{|l|}{ Gulf coast } \\
\hline $\begin{array}{l}\text { Johnson's Bayou } \\
\text { Ft. Morgan }\end{array}$ & $\begin{array}{l}\text { spring } \\
\text { fall }\end{array}$ & $\begin{array}{l}0.29 \\
0.45\end{array}$ & $\begin{array}{l}0.05 \\
<0.01\end{array}$ & $\begin{array}{l}-0.26 \\
-0.40\end{array}$ & $\begin{array}{l}0.09 \\
0.01\end{array}$ & $\begin{array}{l}0.07 \\
0.17\end{array}$ & $\begin{array}{l}0.66 \\
0.27\end{array}$ \\
\hline
\end{tabular}


useful information about stopover abundance. Likely explanations for the unimportance of our density index include the possibility that abundance on single Breeding Bird Survey routes is a poor representation of the density of species.

We found it intriguing that the site where biogeographic effects were least apparent, Johnson's Bayou, was being used by birds after crossing the Gulf of Mexico, a well known migration barrier. The other sites in both seasons were used by birds that had traversed large land masses. Therefore, the difference between patterns found at Johnson's Bayou and other sites may reflect a difference between the migration strategies of warblers crossing barriers and those crossing land masses that contain a matrix of stopover sites. Migrants crossing the Gulf of Mexico also may be more sensitive to weather patterns, as is evident from large daily variation in abundance of migrants associated with weather conditions at Johnson's Bayou (W. Yong, pers. observ.). Furthermore, during spring migration the proximity of sites to the winter range may be an important source of variation in capture rates. For instance, the abundance of migrants may be more influenced by winter biogeography at Johnson's Bayou than in the Middle Rio Grande Valley because the former is closer to the winter range of many Wood Warblers. Perhaps as our understanding of winter biogeography improves we will be able to examine such effects quantitatively. Finally, because birds captured at Ft. Morgan were preparing for trans-Gulf migration, we anticipated that there might have been differences between this site and the Middle Rio Grande Valley. Yet, the similarity of patterns between these sites was more striking than any difference. This similarity is consistent with the possibility that migrants use a common set of movement rules to cross landscapes that contain a matrix of stopover sites.

\section{CONSERVATION IMPLICATIONS}

Although documenting broad-scale patterns contributes to our understanding of migration, it often does not provide the type of detailed quantitative information that is necessary for making decisions about conservation at local sites. At the same time, it is difficult for managers of local sites to develop conservation plans for migrants without a quantitative view of migration at a broad scale. For these reasons it would be useful to generate an expected (i.e., null) abundance of migrants for local sites that reflected our understanding of broad-scale migration patterns. This distribution could then be compared with the abundance of migrants observed at local sites. This type of analysis would allow managers to use local data to identify species that are inordinately abundant regionally. Toward this end, we suggest incorporating biogeographic analyses similar to the ones we present here. For example, in the Middle Rio Grande Valley we examined the residuals of our biogeographic regression analyses (Fig. 1) and found that MacGillivray's, Wilson's, and Virginia's Warblers were among the five species with the greatest positive residuals in both spring and fall, indicating that they were more common than expected from biogeographic patterns. From these results we argue that the Middle Rio Grande is a particularly good place to establish monitoring programs for these warblers.

Another potential application of biogeographic analyses is in the evaluation of the relative importance of stopover sites for conservation. That is, if biogeographic parameters can be used to reliably predict the abundance of migrants at local sites, then it may be possible to locate regions that are likely to contain inordinately important stopover sites without having detailed data from every potential site. This ability would be an extremely useful conservation tool, but will require that more thorough and sophisticated models be tested against rigorously collected data from a broad geographic range.

In summary, we think that summer biogeography has an important influence on the distribution and abundance of North American wood warblers. We suggest that our understanding of broad-scale migration patterns might be improved by including biogeographic parameters in analyses of migrant biology. Finally, such biogeographic analyses may provide a quantitative means of evaluating the value of stopover habitats for migrants that can be used to establish management priorities.

\section{ACKNOWLEDGMENTS}

We thank the Bosque del Apache and Bon Secour National Wildlife Refuges, and Rio Grande Nature Center for allowing access to their land. M. D. Means provided superior database management and technical support. We thank S. and N. Cox, and C. Hundertmark of Rio Grande Bird Research Inc., and John Taylor of the Bosque del Apache NWR for assistance with logistics. 
For field work we thank G. R. Bodner, D. L. Hawksworth, and M. D. Means. J-L Cartron, J. Clark, D. Cimprich, B. Dunning, C. Dywer, M. Guilfoyle, R. King, S. Mabey, S. Morris, J. Owen, C. Szell, M. Woodrey, and S. Woltzman provided useful comments on the manuscript.

\section{LITERATURE CITED}

BIEBACH, H., W. FrIEDRICH, AND G. HIENE. 1986. Interactions of body mass, fat, foraging and stopover period in trans-Saharan migrant passerine birds. Oecologia 69:370-379.

BibBy, C. J., N. D. Burgess, AND D. A. Hill. 1992. Bird census techniques. Academic Press, London.

Bock, C. E. 1987. The distribution-abundance relationships of some Arizona landbirds: a matter of scale? Ecology 68:124-129.

Brown, J. H., AND M. V. Lomolino. 1998. Biogeography. Sinauer, Sunderland, MA.

Brown, J. H., D. W. Mehlman, and G. C. Stevens. 1995. Spatial variation in abundance. Ecology 76: 2028-2043.

DunN, E. H., D. J. T. Hussell, AND R. J. AdAms. 1997. Monitoring songbird population change with autumn mist netting. J. Wildl. Manage. 61:389-396.

FinCH, D. M., AND W. YoNG. In press. Landbird migration in riparian habitats of the Middle Rio Grande: a case study. Stud. Avian Biol.

Gaston, K. J. 1988. Patterns in the local and regional dynamics of moth populations. Oikos 53:49-59.

Gaston, K. J. 1994. Rarity. Chapman and Hall, London.

Gaston, K. J., AND J. L. CuRnutT. 1998. The dynamics of abundance-range size relationships. Oikos 81: 38-41.

Gotelli, N. J., AND D. S. Simberloff 1987. The distribution and abundance of tallgrass prairie plants: a test of the core-satellite hypothesis. Am. Nat. 130:18-35.

Howell, S. N. G., AND S. WEBB. A guide to the birds of Mexico and northern Central America. Oxford Univ. Press, Oxford.

Hussell, D. J. T., AND C. J. RAlPh. 1995. Recommended methods for monitoring bird populations by counting and capture of migrants. N. Am. Migration Monitoring Council, Canadian Wildl. Serv., Ottawa, and U.S. Geological Survey, Laurel, MD.

HutTo, R. L. 1985. Habitat selection by nonbreeding, migratory land birds, p. 455-476. In M. L. Cody [ed.], Habitat selection in birds. Academic Press, New York.

JAMES, F. C., C. E. McCulloch, AND D. A. WiedenFELD. 1996. New approaches to the analysis of population trends in land birds. Ecology 77:1328.

KARR, J. R. 1981. Surveying birds with mist nets. Stud. Avian Biol. 6:62-66.

LAwTON, J. H. 1993. Range, populations abundance and conservation. Trends Ecol. Evol. 8:409-413.

MAcArthur, R. H., AND A. T. MACARTHUR. 1974. On the use of mist nets for population studies of birds. Proc. Natl. Acad. Sci. 71:3230-3233.

MAurer, B. A., AND S. G. HeYwood. 1993. Geograph- ic range fragmentation and abundance in Neotropical migrant birds. Conserv. Biol. 7:501-509.

Mehlman, D. W. 1994. Rarity in North American passerine birds. Conserv. Biol. 8:1141-1145.

Moore, F. R., S. A. Gautheaux JR., P. Kerlinger, and T. R. SIMONS. 1995. Habitat requirements during migration: important link in conservation, p. 121144. In T. E. Martin and D. M. Finch [eds.], Ecology and management of Neotropical migratory birds. Oxford Univ. Press, Oxford.

Moore, F. R., AND P. KeRLINGER. 1987. Stopover and fat deposition by North American wood warblers (Parulinae) following spring migration over the Gulf of Mexico. Oecologia 74:47-54.

MoORE, F. R., P. KeRLINGER, AND T. R. Simons. 1990. Stopover on a Gulf coast barrier island by spring trans-Gulf migrants. Wilson Bull. 102:487-500.

MoORE, F. R., AND T. R. SIMONS. 1992. Habitat suitability and stopover ecology of Neotropical landbird migrants, p. 345-355. In J. M. Hagan III and D. F. Johnston [eds.], Ecology and conservation of Neotropical migrant landbirds. Smithson. Inst. Press, Washington, DC.

Peterjohn, B. G., J. R. Sauer, and C. S. Robbins. 1995. Population trends from the North American Breeding Bird Survey, p. 3-39. In T. E. Martin and D. M. Finch [eds.], Ecology and management of Neotropical migratory birds. Oxford Univ. Press, Oxford.

Price, J., S. Droege, AND A. Price. 1995. The summer atlas of North American birds. Academic Press, London.

Rappole, J. H., E. S. Morton, T. E. Lovejoy III, AND J. L. Rous. 1983. Nearctic avian migrants in the Neotropics. U.S. Dept. Interior, Fish and Wildl. Serv., U.S. Government Printing Office, Washington, DC.

REED, J. M. 1993. A system for ranking conservation priorities for Neotropical migrant birds based on relative susceptibility to extinction, p. 524-536. In J. M. Hagan III and D. F. Johnston [eds.], Ecology and conservation of Neotropical migrant landbirds. Smithson. Inst. Press, Washington DC.

REMSEN, J. V., JR., AND D. A. GoOD. 1996. Misuse of data from mist-net captures to assess relative abundance in bird populations. Auk 113:381-399.

Ridgely, R. S., AND G. TudoR. 1989. The birds of South America: the oscine passerines. Univ. Texas Press, Austin, TX.

Robbins, C. S., J. R. SAuer, R. S. Greenberg, and S. Droege. 1989. Population declines in North American birds that migrate to the neotropics. Proc. Natl. Acad. Sci. 86:7658-7662.

ScotT, S. L. 1987. Field guide to the birds of North America. Natl. Geogr. Soc., Washington, DC.

SOKAL, R. R., AND F. J. RoHLF. 1981. Biometry. W. H. Freeman, San Francisco.

SPSS. 1997. SPSS advanced statistics 7.5. SPSS Inc., Chicago.

Yong, W., AND D. M. FINCH. 1997. Population trends of migratory landbirds along the Middle Rio Grande. Southwest. Nat. 42:137-147.

Yong, W., D. M. Finch, F. R. MoOre, AND J. F. Kelly. 1998. Stopover patterns and habitat use of transient Wilson's Warbler: age- and sex-perspectives. Auk 115:829-842. 